\title{
HYDROGEL AND WATER REGIMES IN THE CHLOROPHYLL-A FLUORESCENCE AND GROWTH OF Campomanesia xanthocarpa SEEDLINGS
}

\author{
Cleberton C. Santos $^{1 *}$, Juliana M. Silverio ${ }^{1}$, Silvana de P. Q. Scalon ${ }^{1}$, Maria do C. Vieira ${ }^{1}$ \\ ${ }^{1 *}$ Corresponding author. Universidade Federal da Grande Dourados/ Dourados - MS, Brazil. \\ Email: cleber_frs@yahoo.com.br| ORCID ID: https://orcid.org/0000-0001-6741-2622
}

KEYWORDS
Dickson quality,
physiological indexes,
photosystem II,
water-retaining
polymer, water
retention capacity.

\begin{abstract}
Water availability is one of the most important factors for the growth of tree seedlings in forestry-related regions. We hypothesized that under different water regimes, a waterretaining polymer (hydrogel) can positively contribute to chlorophyll- $a$ fluorescence and growth in Campomanesia xanthocarpa (Mart.) O. Berg. Four water retention capacities (WRC) were evaluated: $25 \%, 50 \%, 75 \%$, and $100 \%$, depending on the presence or absence of hydrogel at the substrate. The lowest WRCs, particularly those under $25 \%$ without hydrogel, reduced chlorophyll index and negatively affected the photochemical activities of photosystem II. However, under low water availability the hydrogel mitigated the damage inflicted on the reaction centers and chlorophyll synthesis. The greatest growth effects occurred at $100 \%$ WRC in the presence of the hydrogel. Physiological indices were higher under 100\% WRC without hydrogel and 50\% with hydrogel. The increase in biomass and Dickson quality were more pronounced in the seedlings produced under 50\% WRC and hydrogel, and the addition of these parameters to the substrate contributed to more viable morphophysiological indicators for the production of $C$. xanthocarpa seedlings.
\end{abstract}

\section{INTRODUCTION}

In areas of forest recomposition/degradation or regions involved in the formation of integrated sustainable base production systems, water availability in the soil is a determining factor for the growth and initial establishment of tree species seedlings. The difficulty in implementation of irrigation systems and/or the irregularity of precipitation in these areas at certain times of the year are the main limiting factors for water accessibility (Mátyás \& Sun, 2014).

With the reduction of water availability in the soil, the growth characteristics of seedlings are reduced due to instability of the leaf metabolism and damage to the reaction centers of photosystem II (PS II) (Khatri \& Rathore, 2019; Reis et al., 2020), impeding the initial formation. Environmental stress mitigation agents are required in these situations in order to maintain the quality of tree seedlings.

Water-retaining polymers (WRP), known as hydrogels, have the capacity to absorb water and retain it for use during dry periods (Kalhapure et al., 2016; Silva et al., 2019). The composition base of the hydrogel contains polyacrylamide, which when incorporated into the soil, promotes aeration and drainage improvements and reduces nutrient leaching (Azevedo et al., 2002; Freitas et al., 2019), contributing to root and other vegetative organ growth through the stability of metabolic processes and the prevention of plant dehydration.

Therefore, the use of hydrogels may be an alternative for seedlings planted in recovery areas of previously degraded forests, aiding in the success of silvicultural activities (Fonseca et al., 2017). Seedlings of some tree species have shown strong growth responses with hydrogel addition to the soil, including Handroanthus ochraceus (Cham.) Mattos (Mews et al., 2015), Mimosa scabrella Benth. (Konzen et al., 2017), Eucalyptus urophylla $\times$ Eucalyptus grandis (Teixeira et al., 2019), and Enterolobium contortisiliquum (Vell.) Morong. (Turchetto et al., 2020).

Among the species with the potential to recover degraded areas in the Cerrado, Brazil, or to be included in agroforestry systems, Campomanesia xanthocarpa (Mart.) O. Berg. (Myrtaceae) is a native, fruitful tree species,

${ }^{1}$ Universidade Federal da Grande Dourados/ Dourados - MS, Brazil.

Area Editor: Edna Maria Bonfim-Silva

Received in: 7-27-2020

Accepted in: 3-27-2021 
popularly known as "guabiroba," "guavirova," or "gabiroba," with fruits that can be consumed in natura and are attractive to avifauna. This species is located in different forest configurations, and develops preferentially in moist soils from alluvial formations, capons, and more open areas of secondary forest, as well as in regions of the Cerrado (Gogosz et al., 2010; Teleginski et al., 2018).

Considering that $C$. xanthocarpa generally grows in areas with moist and well-drained soils, we hypothesized that, since the photochemical metabolism and growth of seedlings are reduced under low water availability, the incorporation of WRP into the substrate may mitigate the damage to PS II and other morphometric aspects. Thus, the aim of this study was to evaluate the effect of waterretaining polymers on chlorophyll- $a$ fluorescence and the quality of $C$. xanthocarpa seedlings subjected to different water regimes.

\section{MATERIAL AND METHODS}

The experiment was conducted at the Faculty of Agricultural Sciences $\left(22^{\circ} 11^{\prime} 43.7^{\prime \prime} \mathrm{S}\right.$ and 54 $4^{\circ} 56^{\prime} 08.5^{\prime \prime} \mathrm{W}$, $452 \mathrm{~m}$ ), at the Federal University of Grande Dourados (UFGD), Dourados, Mato Grosso do Sul (MS), Brazil, using the species $C$. xanthocarpa, whose exsiccate is deposited at the Herbarium of UFGD (DDMS) under No. 4644. Ripe fruits of this species were collected from the matrices of natural populations (Access Register No. A9CDAAE-CGEN-MMA) in the Itamarati Settlement, city

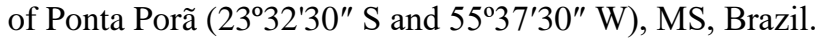

The fruits were manually pulped, and the seeds were immersed in sodium hypochlorite solution $(2 \%)$ for $5 \mathrm{~min}$. Sowing was performed in 72 cell polystyrene trays filled with Tropstrato ${ }^{\circledR}$. When the seedlings reached $3.0 \mathrm{~cm}$ in height, 60 days after sowing, they were moved to $290 \mathrm{~cm}^{3}$ polyethylene tubes, and remained in the nursery with $50 \%$ shading and daily irrigation.

When the seedlings grew to an average height of 6.0 $\mathrm{cm}$, they were transferred to plastic pots filled with $1.5 \mathrm{~kg}$ of Dystrophic Red Latosol + sand (3:1, v/v), with water and hydrogel in the corresponding portions. The seedlings were placed in a nursery with $30 \%$ shading, with additional protection from rainfall by $150 \mu \mathrm{m}$ thick top and side plastic covers. The soil presented the following chemical attributes: $\mathrm{pH} \mathrm{CaCl}_{2}=5.67 ; \mathrm{P}=27.92 \mathrm{mg} \mathrm{dm}^{-3} ; \mathrm{K}=0.63 \mathrm{cmol}_{\mathrm{c}} \mathrm{dm}^{-3} ; \mathrm{Ca}=$ $8.55 \mathrm{cmol}_{\mathrm{c}} \mathrm{dm}^{-3} ; \mathrm{Mg}=2.04 \mathrm{cmol}_{\mathrm{c}} \mathrm{dm}^{-3} ; \mathrm{Al}=0.00 \mathrm{cmol}_{\mathrm{c}} \mathrm{dm}^{-3}$; $\mathrm{H}+\mathrm{Al}=2.37 \mathrm{cmol}_{\mathrm{c}} \mathrm{dm}^{-3}$; sum of bases $=11.22 \mathrm{cmol}_{\mathrm{c}} \mathrm{dm}^{-3}$; cationic exchange capacity $=13.59 \mathrm{cmol}_{\mathrm{c}} \mathrm{dm}^{-3} ; \mathrm{S}=4.22 \mathrm{mg}$ $\mathrm{dm}^{-3} ; \mathrm{B}=0.48 \mathrm{mg} \mathrm{dm}^{-3} ; \mathrm{Fe}=52.13 \mathrm{mg} \mathrm{dm}^{-3} ; \mathrm{Cu}=3.90 \mathrm{mg} \mathrm{dm}^{-}$ 3; $\mathrm{Mn}=78.60 \mathrm{mg} \mathrm{dm}^{-3} ; \mathrm{Zn}=1.75 \mathrm{mg} \mathrm{dm}^{-3}$; organic matter= $20.82 \mathrm{~g} \mathrm{dm}^{-3}$; and base saturation $(\mathrm{V} \%)=82.6$.

The seedlings were grown according to four water regimes, based on the water retention capacity (WRC) of the substrates: $25 \%, 50 \%, 75 \%$, and $100 \%$, and whether waterretaining polymers (WRP) were added to the substrate. The treatments were arranged in a $4 \times 2$ factorial scheme, in a randomized block design with four replications, with each experimental unit consisting of four pots containing one plant each.

The water retention capacity was determined on alternate days using the gravimetric method (Souza et al., 2000). Forth $\mathrm{Gel}^{\circledR}$ was the hydrogel used as the waterretaining polymer, consisting of polyacrylic potassium polyacrylamide (soil conditioner - class $\mathrm{E}$; $\mathrm{CEC}=53.22$ $\mathrm{cmol}_{\mathrm{c}} \mathrm{dm}^{3}$ ) at a dose of $4 \mathrm{~g} \mathrm{~L}^{-1}$ substrate, added in an incorporated granule form and homogenized to the substrate. Three hours before transplanting the seedlings the substrate was moistened.

Sixty days after transplanting, the seedlings were evaluated for chlorophyll- $a$ fluorescence and growth characteristics as follows:

a) Chlorophyll index (SPAD): obtained using a portable chlorophyll meter SPAD 502 (Soil Plant Analyzer Development), with the evaluation carried out between 8:00 to 10:00 a.m.;

b) Chlorophyll- $a$ fluorescence: fully expanded leaves were subjected to dark conditions using leaf clips for $30 \mathrm{~min}$, and subsequently, using a flash of $1,500 \mu \mathrm{mol} \mathrm{m} \mathrm{m}^{-2} \mathrm{~s}^{-1}$, with a portable fluorometer (OS-30p; Opti-Sciences Chlorophyll Fluorometer, Hudson, NY, USA), the emission of the initial $\left(\mathrm{F}_{0}\right)$ and maximum $\left(\mathrm{F}_{\mathrm{m}}\right)$ chlorophyll- $a$ fluorescence and the potential photochemical efficiency of photosystem II $\left(F_{v} / F_{m}\right)$ were evaluated. The variable fluorescence $\left(F_{v}=F_{m}\right.$ - $\left.F_{0}\right)$, efficiency of conversion of absorbed energy $\left(F_{v} / F_{0}\right)$, and the maximum basal yield of non-photochemical processes $\left(\mathrm{F}_{0} / \mathrm{F}_{\mathrm{m}}\right)$ were determined, and the results were expressed as electrons per quantum;

c) Growth: the height of plants was determined using a ruler graduated in millimeters, considering the evaluation standard, distance between the collar to the inflection of the highest leaf $(\mathrm{cm})$, stem diameter $(\mathrm{mm}$, with digital calipers 1.0 above the substrate level), and the number of leaves (NL). The seedlings were then harvested, separated into leaves, stems, and roots, and the leaf area $\left(\mathrm{LA}, \mathrm{cm}^{2}\right)$ was determined using an area integrator (LI-COR, $3100 \mathrm{C}-$ Area Meter, NE, USA), and the length of the largest root was measured with a ruler graduated in centimeters;

d) Production, physiological indexes, and quality of seedlings: The different organs were placed in an oven with forced air circulation at $60 \pm 5{ }^{\circ} \mathrm{C}$ until the mass was stabilized, followed by weight assessment on a precision scale $(0.0001 \mathrm{~g})$. From the leaf area and dry biomass data, the leaf area ratio (LAR, $\mathrm{cm}^{2} \mathrm{~g}^{-1}$ ), specific leaf area (SLA, $\mathrm{cm}^{2} \mathrm{~g}^{-1}$ ), and specific leaf mass (SLM, $\mathrm{g} \mathrm{cm}^{-2}$ ) were calculated (Benincasa, 2003). The seedling quality index (DQI) was determined according to the proposal of Dickson et al. (1960).

The data were subjected to analysis of variance (ANOVA), and when significant differences were detected (F test, $p<0.05$ ), the means were compared using the Bonferroni $t$ test for the water-retaining polymer, and Tukey's test for water retention capacity $(p \leq 0.05)$, using the SISVAR software (Ferreira, 2019).

\section{RESULTS AND DISCUSSION}

The water regimes affected the photochemical characteristics of photosynthesis and initial growth of $C$. xanthocarpa seedlings, and the lower water retention capacities (WRC) of $25 \%$ and $50 \%$ in the substrate produced lower values, indicating a water deficit; however, the addition of the water-retaining polymer (WRP) contributed to mitigating the damage caused to the various indicators evaluated, particularly under low water availability, which corroborates our hypothesis. 
Seedlings produced under $25 \%$ and 50\% WRC without WRP showed a lower chlorophyll index (Figure 1a), while those under $25 \%$ WRC with WRP showed an increase in this measure, with values close to those of seedlings with $75 \%$ or $100 \%$ WRC without WRP. However, the addition of WRP to the substrate and maintenance of $100 \%$ WRC caused a reduction in the SPAD index.

The indicators of chlorophyll- $a$ fluorescence and activities on photosystem II were influenced by the interaction between the factors under study, apart from the
$\mathrm{F}_{\mathrm{m}}(p<0.05)$. The lower water availability $(25 \% \mathrm{WRC})$ in the substrate without WRP resulted in an increase in $\mathrm{F}_{0}$ ( 0.280 electrons per quantum) (Figure 1b) and a decrease in $\mathrm{F}_{\mathrm{v}}$ (0.098 electrons per quantum) (Figure 1c), indicating oxidative damage to the chloroplast. In general, with $25 \%$ and $50 \%$ of the WRC and the absence of WRP, the seedlings reduced the efficiency of PS II $\left(\mathrm{F}_{\mathrm{v}} / \mathrm{F}_{\mathrm{m}}\right)$ (Figure 1d) and absorbed energy conversion $\left(F_{v} / F_{0}\right)$ (Figure $\left.1 e\right)$, causing an increase in the yield of non-photochemical processes $\left(\mathrm{F}_{0} / \mathrm{F}_{\mathrm{m}}\right)($ Figure 1f).
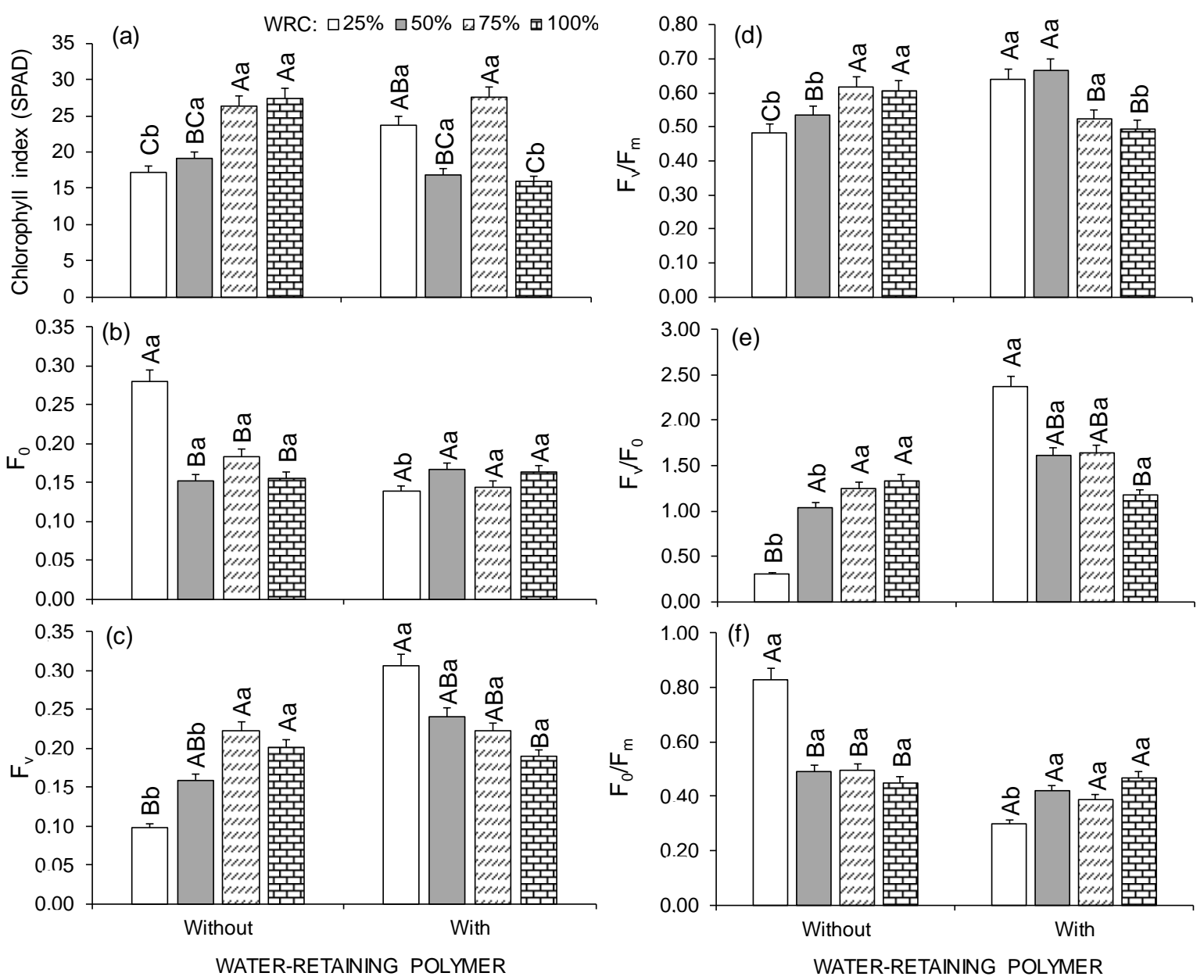

FIGURE 1. Chlorophyll index (a), initial $-\mathrm{F}_{0}(\mathrm{~b})$ and variable $-\mathrm{F}_{\mathrm{v}}$ (c) fluorescence, potential photochemical efficiency of photosystem II $-F_{v} / F_{m}$ (d), efficiency of conversion of absorbed energy $-F_{v} / F_{0}$ (e) and maximum basal yield of nonphotochemical processes $-\mathrm{F}_{0} / \mathrm{F}_{\mathrm{m}}$ (f) in leaves of $C$. xanthocarpa seedlings in function of association water-retaining polymer and water retention capacity - WRC on substrate. Uppercase letters compare the different WRC within the use of WRP (Tukey, $p<0.05$ ) and lowercase letters compare the use of WRP within each WRC (Bonferroni $t$ test, $p<0.05$ ).

A partial inactivation in the $\mathrm{P}_{680}$ reaction centers results from a reduction in the potential collector of light energy in the antenna complex and transfer to the acceptors, indicated by the increase in $\mathrm{F}_{0}$ and $\mathrm{F}_{0} / \mathrm{F}_{\mathrm{m}}$ and decrease in the other photochemical indicators under water deficit (Meng et al., 2016; Khatri \& Rathore, 2019; Faseela et al., 2020). Thus, a decline in the flow of electrons occurs in the transport chain, particularly those of plastoquinone A, and the reduced chlorophyll synthesis and tissue dehydration causes the conversion of absorbed energy (Zheng et al., 2019; Badr \& Brüggemann, 2020), promoting energy dissipation and photochemical apparatus alterations.

When WRP was incorporated into the substrate, the photochemical processes were stable, especially under $25 \%$ and $50 \% \mathrm{WRC}$, reinforcing our hypothesis that the hydrogel attenuates the damage in the reaction centers even under low water availability, returning values similar to those of seedlings with the largest WRC, without WRP. The polymer is formed by a hydrophilic group able to absorb up to 400 times its weight in water. Therefore, when water potential begins to decrease in the substrate, the gel uniformly supplies up to $95 \%$ of the water that has been stored in the soil, thus mitigating the water deficit (Kalhapure et al., 2016) and regulating electron transfer, energy balance, and leaf metabolism.

However, we found that seedlings with $75 \%$ and $100 \%$ WRC and the addition of WRP presented lower values of $F_{v} / F_{m}$ and $F_{v} / F_{0}$, indicating stress, since there was sufficient irrigation with the WRC, along with the water stored in the WRP. These reductions may be associated with water 
saturation, supra-optimal conditions beyond the required levels; thus, seedlings show symptoms of stress likely in relation to the production of reactive oxygen species (ROS); reduction of $\mathrm{CO}_{2}$ fixation, causing lipid peroxidation; and oxidative damage (Hasanuzzaman et al., 2020).

The height of the seedlings was greater $(14.85 \mathrm{~cm})$ with WRP, independent of the WRC (Figure 2a). The stem diameter was larger under $50 \%$ and $100 \%$ WRC with WRP when compared to the same water regimes in the absence of WRP (Figure 2b). As the WRC increased in the substrates, the number of leaves also increased, especially under $100 \%$ without and with WRP (22 and 27 leaves, respectively), and the seedlings grown with WRP presented more expressive values that differed statistically from those without WRP within the regimes of $25 \%, 75 \%$, and $100 \%$ WRC (Figure 2c).
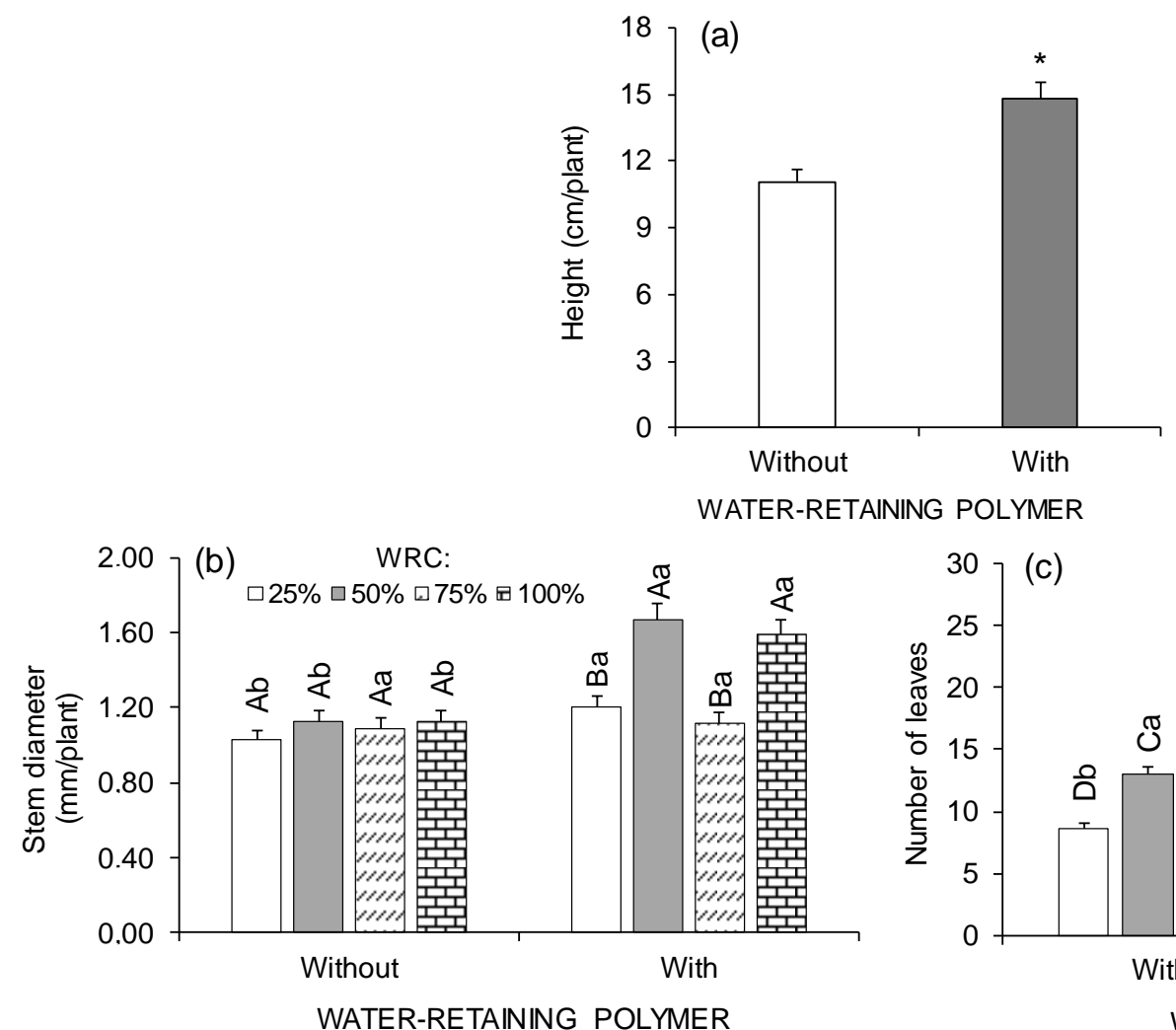

FIGURE 2. Height (a), stem diameter (b) and number of leaves (c) in C. xanthocarpa seedlings in function of association waterretaining polymer and water retention capacity - WRC on substrate. Uppercase letters compare the different WRC within the use of WRP (Tukey, $p<0.05$ ) and lowercase letters compare the use of WRP within each WRC (*Bonferroni $t$ test, $p<0.05$ ).

Our results demonstrate that WRP contributed to the growth of $C$. xanthocarpa through a longer supply of water from the storage of hydrophilic polymer granules. This response was also observed in two cultivars of Olea europaeae L., under two water regimes (without and with water restriction), and addition or absence of hydrogel, where the growth parameters of this species were improved by the hydrogel because of its ability to prevent dehydration damage to young plants (M'Barki et al., 2019).

Regarding the leaf morphological characteristics, hormonal signaling occurs under lower WRC in the substrate, in terms of ABA transport from the roots to the cytosol, reducing leaf expansion both in number and in area, mitigating the transpiratory rate, as well as regulating the conductance in the sub-stomatal and mesophilic chambers for $\mathrm{CO}_{2}$ assimilation (Sorrentino et al., 2016). In contrast, the mechanisms presented by the seedlings under adequate water status keep their metabolic processes stabilized.

The leaf area of the $C$. xanthocarpa seedlings were influenced by the factors alone, with greater values in the seedlings produced with WRP $\left(28.49 \mathrm{~cm}^{2}\right)$ (Figure 3a) and under $100 \%$ WRC $\left(32.96 \mathrm{~cm}^{2}\right)$ (Figure $\left.3 \mathrm{~b}\right)$. The addition of WRP increases the water potential gradient in the substrate (Kalhapure et al., 2016), and water translocates more efficiently through the xylemic vessels to the leaves, expanding their per unit area (Lauri et al., 2014; HernandezSantana et al., 2016), thereby maximizing photosynthetic capacity. Similarly, Tabebuia roseoalba (Ridl.) seedlings had a larger leaf area under $100 \%$ WRC that reduced with lower water availability (Scalon \& Mussury, 2020). 

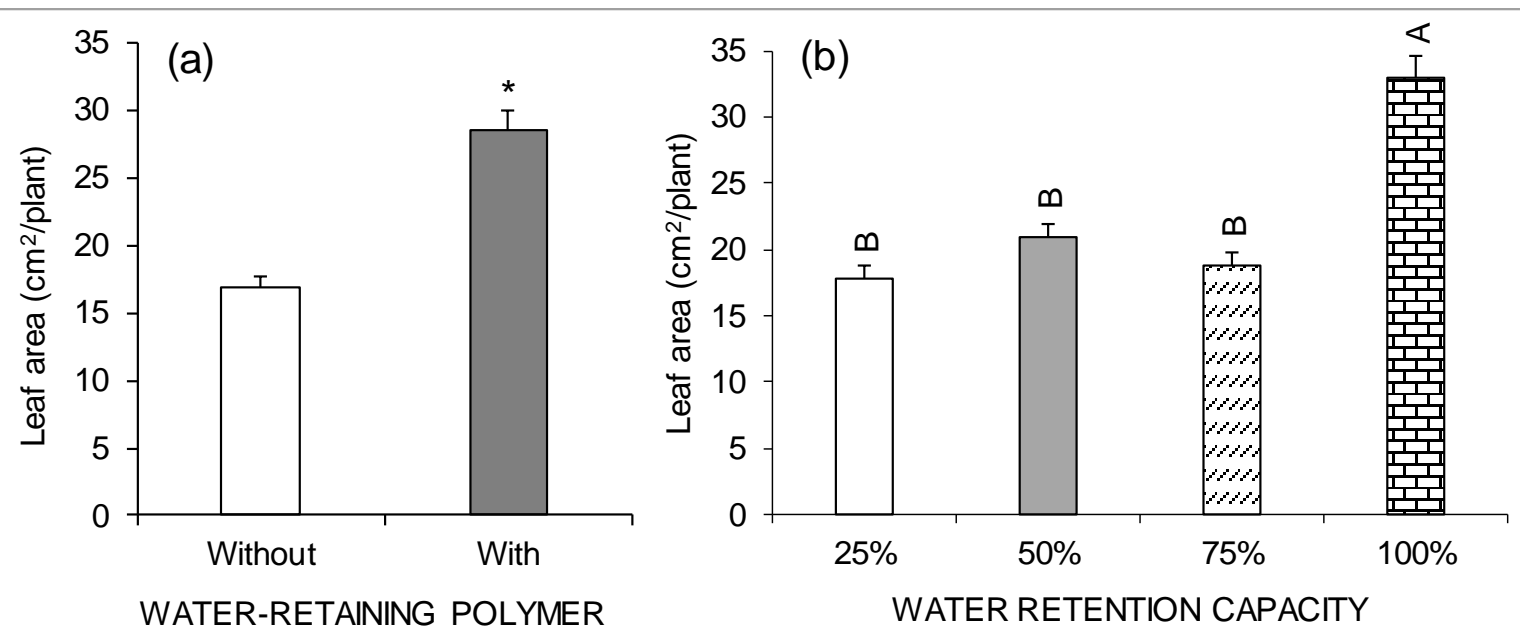

FIGURE 3. Leaf area in C. xanthocarpa seedlings in function of use water-retaining polymer (a) or water retention capacity WRC (b) on substrate. * (Bonferroni $t$ test, $p<0.05$ ); Equal letters between columns in WRC not differ from each other (Tukey, $p>0.05)$.

The length of the largest root averaged $22.0 \mathrm{~cm}$ and was not influenced by the factors under study $(p>0.05)$. Conversely, the physiological indexes were influenced by factor interactions, with the highest LAR values (266.81 and $233.73 \mathrm{~cm}^{2} \mathrm{~g}^{-1}$ ) occurring in the seedlings with $100 \%$ and $50 \%$ WRC, without and with WRP, respectively (Figure 4a). The values of SLA and SLM showed the same trend, higher values in seedlings under $100 \%$ WRC without WRP, while only the $50 \%$ WRC with WRP group presented lower values compared to the other water regimes (Figure $4 \mathrm{~b}$ and $4 \mathrm{c})$.

The responses of the physiological indexes to seedlings in these water conditions, especially $50 \% \mathrm{WRC}$ with WRP, demonstrate an increase in structural tissues for dehydration protection, allowing less stomatal limitation under adverse environmental conditions (Ricote et al., 2019), and greater photoassimilate production per unit area.

The greatest dry mass of leaves $(0.234 \mathrm{~g} / \mathrm{plant})$ occurred in seedlings produced under $100 \%$ WRC with WRP (Figure 4d), whereas the water regimes without WRP, did not differ statistically. According to Milani et al. (2017), the presence of polyacrylamide in the WRP can increase the hydraulic cohesion and conductivity in the soil, even under deficit, thereby reducing the required frequency or depth of irrigation, as well as maintaining the cell membrane integrity, mitigating the ROS production, and enabling greater biomass allocation of in the seedlings. The stem and root dry masses were not influenced by the factors under study ( $p>0.05)$, with averages of 0.131 and $0.188 \mathrm{~g} /$ plant, respectively.

The aerial part/root ratio (APRR) was higher under $75 \%$ and $50 \%$ WRC, without and with WRP, respectively, and it should be noted that when WRP was added to the substrate, different water regimes, except 50\% WRC, returned statistically higher values when compared to the seedlings without hydrogel (Figure 4e). This increase relates to the benefits of WRP for water retention in the substrate (Freitas et al., 2019), demonstrating investment in root biomass due to greater water absorption, contributing to translocation to the aerial part, promoting better physiological indexes and growth characteristics. 

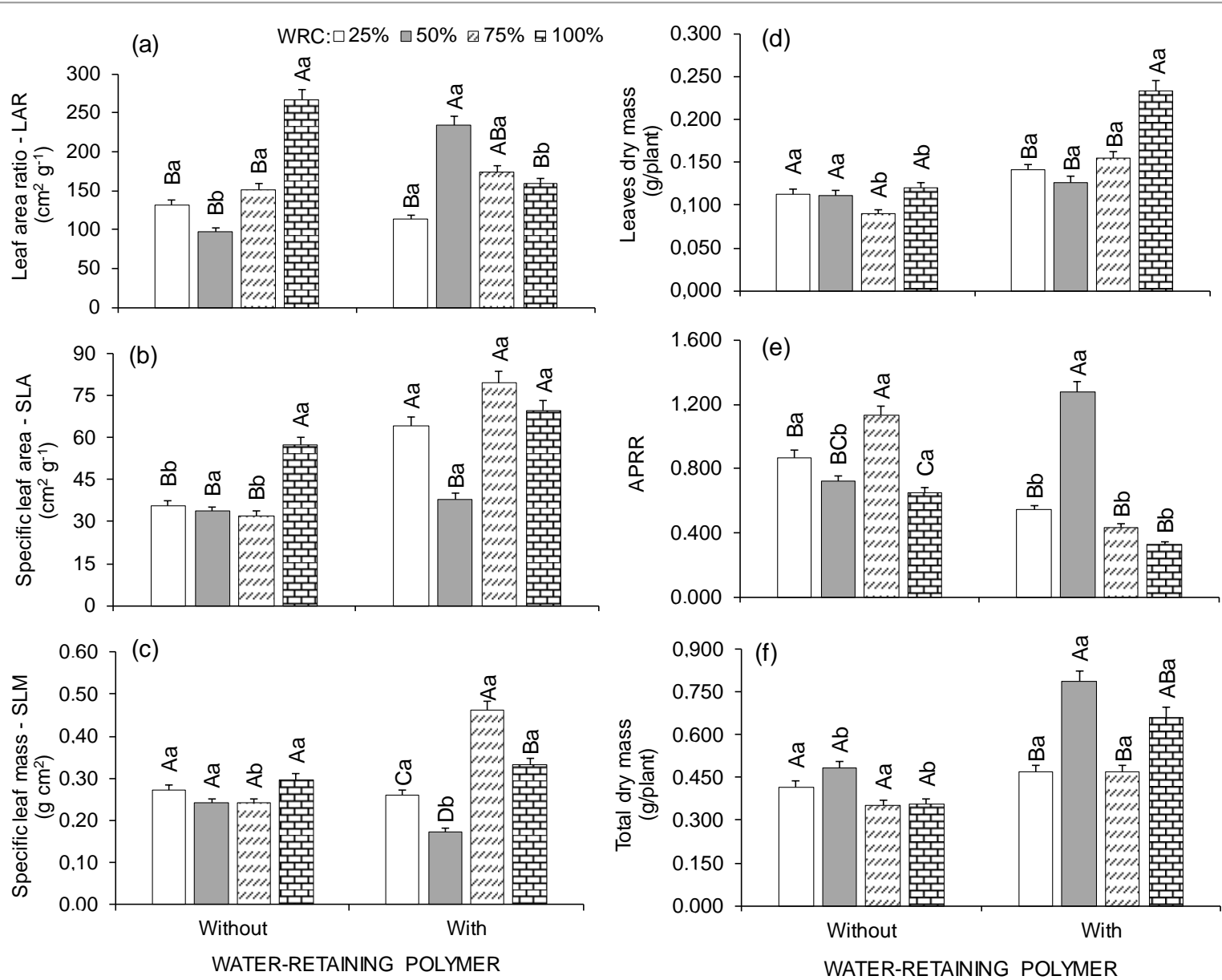

FIGURE 4. Leaf area ratio - LAR (a), specific leaf area - SLA (b), specific leaf mass - SLM (c), leaves (d) aerial part/root ratio - APRR (e) and total dry mass (f) in C. xanthocarpa seedlings in function of association water-retaining polymer and water retention capacity - WRC on substrate. Uppercase letters compare the different WRC within the use of WRP (Tukey, $p<0.05$ ) and lowercase letters compare the use of WRP within each WRC (Bonferroni $t$ test, $p<0.05$ ).

The seedlings showed higher total dry mass yields under $50 \%$ and $100 \%$ WRC, both with WRP (Figure 4f), demonstrating the beneficial effect of the hydrogel on the photoassimilate production. The largest biomasses were associated with the highest vegetative characteristic values of the aerial part, such as the number of leaves (Figure 1c) and leaf area (Figure 3) under the same growing conditions.

The Dickson quality index (DQI) was influenced by the factors separately, with the highest values occurring in seedlings produced with WRP (Figure 5a) and under 50\% WRC (Figure 5b). The increase in DQI in these conditions is associated with the benefits of WRP in terms of growth, APRR, physiological indexes, and biomass. This indicator has been used as a quality parameter for forest seedlings because it makes inferences based on the morphometric characters and photoassimilates partitioning in the different organs.
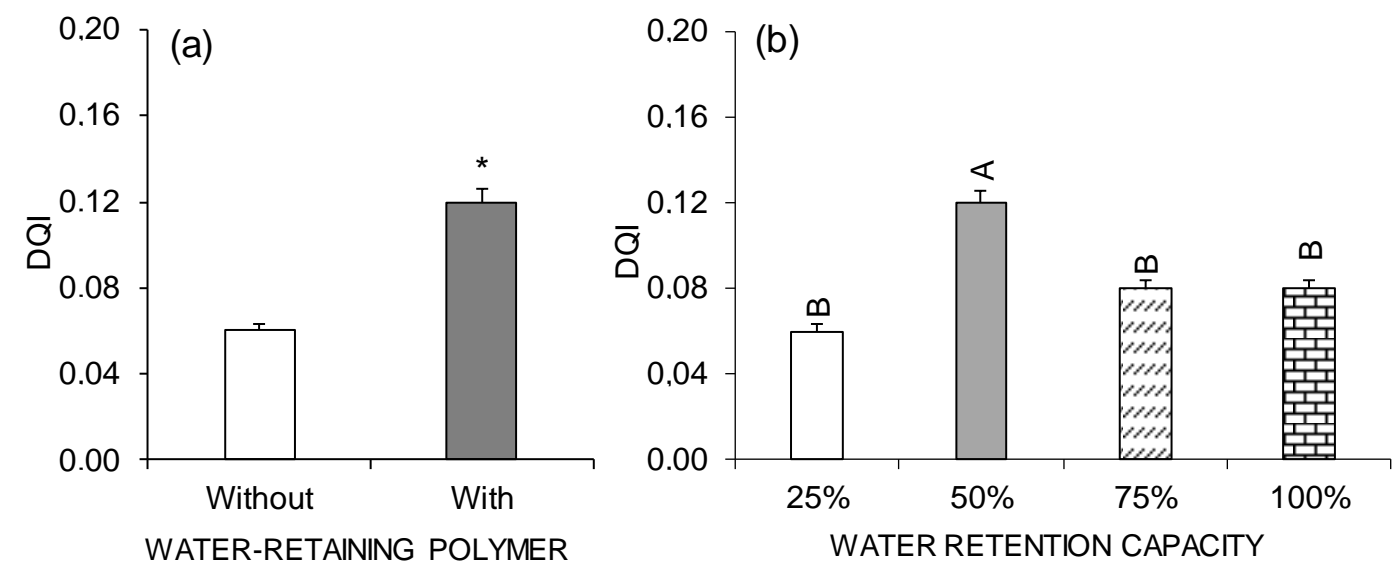

FIGURE 5. Dickson quality index - DQI in C. xanthocarpa seedlings in function of use water-retaining polymer (a) or water retention capacity - WRC (b) on substrate. * (Bonferroni $t$ test, $p<0.05$ ); Equal letters between columns in WRC not differ from each other (Tukey, $p>0.05$ ). 
Although the efficiencies of the photochemical processes of $C$. xanthocarpa seedlings was reduced without WRP, the damage in the reaction centers was reversible as no harm to the biochemical processes of photosynthesis occurred, since there was still an increase in biomass independent of the WRC. However, the addition of WRP maintained the photochemical apparatus integrity by attenuating disturbances in chlorophyll- $a$ fluorescence emissions, thereby enhancing the production of photoassimilates.

Therefore, in regions where irrigation management is challenging or rainfall is irregular, such as the Cerrado, the addition of a water-retaining polymer has a promising mitigating effect, contributing to the quality of seedlings, and reducing costs with its replacement after transplanting, ensuring sound silvicultural practices. However, further studies should be conducted to verify the duration of action of the WRP in the soil and thus determine the ideal time for transplanting the seedlings with the addition of the polymer to the substrate.

\section{CONCLUSIONS}

Water deficiencies destabilize the activities in the photochemical apparatus, compromising the growth of Campomanesia xanthocarpa (Mart.) O. Berg, seedlings; however, a water-retaining polymer can attenuate these deleterious effects. The addition of a hydrogel and attaining a water retention capacity of $50 \%$ promotes greater morphophysiological indicators and quality of seedlings.

\section{ACKNOWLEDGEMENTS}

The authors thank the Foundation for the Development of Education, Science, and Technology of State of Mato Grosso do Sul (FUNDECT) and the Coordination for the Improvement of Higher Education Personnel (CAPES) and the National Council for Scientific and Technological Development $(\mathrm{CNPq})$ for the research scholarship and financial support associated with the development and dissemination of this work.

\section{REFERENCES}

Azevedo TLF, Bertonha A, Gonçalves ACA, Freitas PSL, Frizzone JÁ (2002) Níveis de polímero superabsorvente, frequência de irrigação e crescimento de mudas de café. Acta Scientiarum 24(5): 1239-1243. DOI: http://dx.doi.org/ 10.4025/actasciagron.v24i0.2271

Badr A, Brüggeman W (2020) Comparative analysis of drought stress response of maize genotypes using chlorophyll fluorescence measurements and leaf relative water content. Photosynthetica 58(2): 38-645. DOI: http://dx.doi.org/ 10.32615/ps.2020.014

Benincasa MMP (2003) Análise do crescimento de plantas (noções básicas). Jaboticabal, Funep, 41p.

Dickson A, Leaf AL, Hosner JF (1960) Quality appraisal of white spruce and white pine seedling stock in nurseries. Forestry Chronicle 36(1): 10-13. DOI: http://dx.doi.org/ $10.5558 /$ tfc36010-1
Faseela P, Sinisha AK, Brestič M, Puthur JT (2020) Chlorophyll- $a$ fluorescence parameters as indicators of a particular abiotic stress in rice. Photosynthetica 58(2): 293300. DOI: http://dx.doi.org/ 10.32615/ps.2019.147

Ferreira DF (2019) Sisvar: a computer analysis system to fixed effects Split plot type designs. Revista Brasileira de Biometria 37(4): 529-535. DOI: http://dx.doi.org/ $10.28951 /$ rbb.v37i4.450

Fonseca L, Roitman I, Jacobson TKB, Ogata RS, Solari RAF, Ribeiro RJC (2017) Viabilidade do hidrogel na recuperação de Cerrado sensu stricto com espécies nativas. Floresta e Ambiente 24: 1-8. DOI: http://dx.doi.org/ $10.1590 / 2179-8087.022716$

Freitas JS, Oliveira LFC, Abreu ECF, Almeida AES (2019) Fotodegradação de hidrogel de poliacrilamida na presença de substâncias químicas para o uso na agricultura. Matéria 24(3): 1-8. DOI: http://dx.doi.org/10.1590/s1517-707620190003.0722

Gogosz AM, Cosmo NL, Bona C, Souza A (2010)

Morfoanatomia da plântula de Campomanesia xanthocarpa O. Berg. (Myrtaceae). Acta Botanica Brasileira 24(3): 613-623. DOI: http://dx.doi.org/10.1590/S0102-33062010000300003

Hasanuzzaman M, Bhuyan MHMB, Zulfiqar F, Raza A, Mohsin SM, Mahmud JA, Fujita M, Fotopoulos V (2020) Reactive oxygen species and antioxidant defense in plants under abiotic stress: revisiting the crucial role a universal defense regulator. Antioxidants 9: 1-52. DOI: http://dx.doi.org/10.3390/antiox9080681

Hernandez-Santana V, Roriguez-Dominguez CM, Fernández JE, Diaz-Espejo A (2016) Role of leaf hydraulic conductance in the regulation of stomatal conductance in almond and olive in response to water stress. Tree Physiology 36: 725-736. DOI: http://dx.doi.org/ 10.1093/treephys/tpv146

Kalhapure A, Kumar R, Singh VP, Pandey DS (2016) Hydrogels: a boon for increasing agricultural productivity in water-stressed environment. Current Science 111(11): 1773-1779. DOI: http://dx.doi.org/ $10.18520 / \mathrm{cs} / \mathrm{v} 111 / \mathrm{i} 11 / 1773-1779$

Khatri K, Rathore MS (2019) Photosystem photochemistry, prompt and delayed fluorescence, photosynthetic responses and electron flow in tobacco under drought and salt stress. Photosynthetica 57(1): 6174. DOI: http://dx.doi.org/ 10.32615/ps.2019.028

Konzen ER, Navroski MC, Friederichs G, Ferrari LH, Pereira MO, Felippe D (2017) The use of hydrogel combined with appropriate substrate and fertilizer improve quality and growth performance of Mimosa scabrella Benth. seedlings. Cerne 23(4): 473-482. DOI: http://dx.doi.org/10.1590/01047760201723042440

Lauri PE, Marceron A, Normand F, Dambreville A, Regnard JL (2014) Soil water deficit decreases xylem conductance efficiency relative to leaf area and mass in the Apple. Journal of Plant Hydraulics 1: 1-13. DOI: http://dx.doi.org/10.20870/jph.2014.e003 
Mátyás C, Sun G (2014) Forests in a water limited world under climate change. Environmental Research Letters 9: 110. DOI: http://dx.doi.org/10.1088/1748-9326/9/8/085001

M'bark N, Aissaoui F, Chehab H, Dabbaghi O, Giudice T, Boujnah D, Mechri B (2019) Cultivar dependent impact of soil amendment with water retaining polymer on olive (Olea europaeae L.) under two water regimes. Agricultural Water Management 21: 70-75. DOI: http://dx.doi.org/ 10.1016/j.agwat.2019.01.016

Meng LL, Song JF, Wen J, Zhang J, Wei JH (2016) Effects of drought stress on fluorescence characteristics of photosystem II in leaves of Plectranthus scutellarioides. Photosynthetica 54(3): 414-421. DOI: http://dx.doi.org/ 10.1007/s1 1099-016-0191-0

Mews CL, Sousa JRL, Azevedo GTOS, Souza AM (2015) Efeito do hidrogel e ureia na produção de mudas de Handroanthus ochraceus (Cham.) Mattos. Floresta e Ambiente 22(1): 107-116. DOI:

http://dx.doi.org/10.1590/2179-8087.080814

Milani P, França D, Baliero AG, Faez R (2017) Polymers and its applications in Agriculture. Polímeros 27(3): 256266. DOI: http://dx.doi.org/10.1590/0104-1428.09316

Reis LC, Scalon SPQ, Dresch DM, Foresti AC, Santos CC, Pereira ZV (2020) Chlorophyll- $a$ fluorescence as an indicator of water stress, in Calophyllum brasiliense. Notulae Botanicae Horti Agrobotanici Cluj-Napoca 1(1): 210-220. DOI: http://dx.doi.org/ 10.15835/nbha48111757

Ricote N, Bastias CC, Valladares F, Pérez F, Bozinovic F (2019) Selfing and drought-stress strategies under water deficit for two herbaceous species in the South American Andes. Frontier in Plant Science 10: 1-12. DOI: http://dx.doi.org/ 10.3389/fpls.2019.01595

Scalon SPQ, Mussury RM (2020) Physical-anatomy and initial growth of Tabebuia roseoalba (Ridl.) under different water regimes. Floresta e Ambiente 27(1): 1-7. DOI: http://dx.doi.org/10.1590/2179-8087.056117
Silva LKS, Costa RN, Santos AS, Silva DMR, Santos JCC, Pavão JMS, Moura FBP, Silva JV (2019) Hidrogel melhora o crescimento inicial e qualidade de mudas de Enterolobium contortisiliquum. Scientific Electronic Arquives 12(3): 53-61. DOI: http://dx.doi.org/ $10.36560 / 1232019729$

Sorrentino G, Haworth M, Wahbi S, Mahmood T, Zuomin S, Centrito M (2016) Abscisic acid induces rapid reductions in mesophyll conductance to carbon dioxide. PLoS ONE 11(2): 1-14. DOI: http://dx.doi.org/ 10.1371/journal.pone.0148554

Souza CC, Oliveira FA, Silva IF, Amorin Neto MS (2000) Avaliação de métodos de determinação de água disponível e manejo da irrigação em terra roxa sob cultivo de algodoeiro herbáceo. Revista Brasileira de Engenharia Agrícola e Ambiental 4(3): 338-342. DOI: http://dx.doi.org/10.1590/S1415-43662000000300006

Teixeira CES, Torres AQA, Nieri EM, Melo LA, Santos LV, Botelho AS (2019) Polímero hidroretentor e fertilização mineral na implantação de híbrido de Eucalyptus urophylla $\mathrm{x}$ Eucalyptus grandis. Ciência Florestal 29(3): 1060-1071. DOI: http://dx.doi.org/ $10.5902 / 1980509834950$

Teleginski F, Zuffellato-Ribas KC, Koehler HS, Degenhardt-Goldbach J, Teleginski E (2018) Resgate vegetativo de Campomanesia xanthocarpa (Mart.) ex O. Berg por alporquia. Ciência Florestal 28(2): 820-826. DOI: http://dx.doi.org/ 10.5902/1980509832100

Turchetto F, Araujo MM, Tabaldi LA, Griebeler AM, Berghetti ALP, Rorato DG, Barbosa FF, Sasso VM (2020) Irrigation regime on growth and metabolic processes of Enterolobium contortisiliquum seedlings. Floresta e Ambiente 27(2): 1-11. DOI: http://dx.doi.org/ $10.1590 / 2179-8087.026318$

Zheng HF, Xin LF, Guo JM, Mao J, Han XP, Jia L, Zheng BY, Du CG, Elmore RW, Yang QH, Shao RX (2019) Adaptation of photosynthesis to water deficit in the reproductive phase of a maize inbred line. Photosynthetica 57(2): 399-408. DOI: http://dx.doi.org/ $10.32615 /$ ps.2019.047 